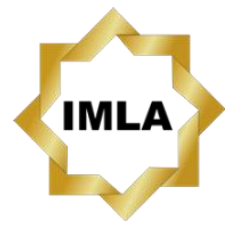

Available online:

http://journal.imla.or.id/index.php/arabi

Arabi : Journal of Arabic Studies, 5 (2), 2020, 130-141

DOI: http://dx.doi.org/10.24865/ajas.v5i2.240

\title{
VALUABLE MORAL MESSAGES IN THE CLASSICAL ARABIC POETRY: SEMIOTIC STUDY OF THE IMAM ALI'S POEMS
}

\author{
Muhammad Lukman Arifianto \\ Universitas Negeri Malang, Indonesia \\ E-mail : muhammad.arifianto.fs@um.ac.id
}

\begin{abstract}
This paper discusses the moral messages implied in the Imam Ali's poems. As stated by some experts, poetry is a set of signs that need to be sought for its meaning and significance. This set of signs is mostly difficult to be realized directly by ordinary people. In consequence, Imam Ali's poems need to be explored by semiotic analysis so that the meanings implied in these poems can be elaborated in detail, and hopefully, it can be well understood by the public. The method used is descriptive-analytical framework that emphasizes systematic interpretation from of the individual point of view or population being studied to generate new concepts. Based on the result, it is found that Imam Ali's poems imply many valuable and important moral messages that were in line with Islamic teachings and they are very important to be known, studied, and used as the guidelines in everyday life. The moral messages implied in these poems they are about the primacy of seeking knowledge and science, the primacy of reasoning, the primacy of silence, keeping away from greedy, and patient with all kinds of insult.
\end{abstract}

Keywords: Arabic poetry, classical poetry, semiotic, Imam Ali ibn Abi Thalib

\begin{abstract}
Abstrak
Artikel ini membahas tentang pesan moral yang tersirat dalam puisi Imam Ali bin Abi Thalib. Menurut beberapa ahli, puisi adalah serangkaian tanda yang perlu dicari makna dan signifikansinya. Rangkaian tanda ini sebagian besar sulit dipahami secara langsung oleh masyarakat awam. Oleh karena itu, puisi-puisi Imam Ali perlu dijabarkan dengan analisis semiotik sehingga makna-makna yang tersirat dalam puisi tersebut dapat dielaborasi secara rinci, sehingga bisa dipahami dengan baik oleh masyarakat. Adapun metode yang digunakan adalah metode deskriptif-analitis yang menekankan pada penafsiran secara sistematis dari sudut pandang individu atau populasi yang sedang dipelajari untuk menghasilkan konsep-konsep baru. Berdasarkan hasil analisis dengan menggunakan, ditemukan bahwa puisi-puisi Imam Ali menyiratkan banyak pesan moral penting dan berharga yang sejalan dengan ajaran Islam. Pesan moral ini sangat penting untuk diketahui, dipelajari, dan dijadikan sebagai pedoman hidup sehari-hari. Pesan-pesan moral yang terkandung dalam puisi ini, antara lain, adalah tentang keutamaan menuntut ilmu, keutamaan akal, keutamaan diam, menjauhkan diri dari keserakahan, dan bersabar dengan segala macam cacian atau hinaan.
\end{abstract}

Kata Kunci: puisi Arab, puisi klasik, semiotik, Imam Ali bin Abi Thalib 


\section{Introduction}

Poetry is a great cultural identity for the Arab society. As the cultural identity, it certainly reflects the thoughts and feelings of the Arab nation with all its excess and deficiency (Manshur, 2007:1). Arabic poetry is not only a reflection picture from their daily life, but also a great phenomenon that can unite the Arab nation (Syatayawi, 2013:3).

In the pre-Islamic times, Arabic poetry became the main foundation and was seen as a basic rule in the principles of poetry (Mansur, 2007:3). The topics or genres most frequently used and become the domain of pre-Islamic Arabic poetry are about the pride (fakhr), the praise (madh), the satire (hija), the elegy (ritsa), the description (washf), and the love (ghazal) (Mansur, 2007:3; Badawi, 1975:3).

The birth of the Prophet Muhammad (PBUH) marked the beginning of a new era (Islam) which it slowly changed the way of life and ideology of the Arabs with the Quran as its main foundation (Bakalla, 1984:136). The arrival of Islam packaged with the Quran as its main foundation was able to influence the development of the poetry at the time. The first generation of Muslim poets was Arabs who lives in a tradition that had the established poetry conventions and rules. (Manshur, 2007:4; Asriyah, 2016:95).

Islam came with its own values, making the literary works developed at that time by those values (religious) in majority. This influence can be seen from the shift in topics or themes developed in the poems in that era (the early history of Islam). In addition, the influence of the Quranic language also appears in the poems of this era, especially in terms of the word choices (Zaidan, 2013:236).

Poetry, as one of the literary genres, is not just a series of ordinary words. According to Culler (2001:5), poetry is an expression of a person's attitude expressed through the words in certain patterns and tones. Pradopo (2010:7) also said that the poetry expresses thoughts that can arouse human feelings and stimulate the imagination of the five senses in a rhythmic arrangement. Thus, the poetry is a recording and interpretation of important human experiences and it is composed in the most memorable form (oral and written).

One of the most famous and well-known Arabic poems in the classical period of Arabic poetry (also known as the early history Islam) is the poems attributed to Imam Ali ibn Abi Talib ("Imam Ali" will be written hereafter). The poems attributed to him generally contain the good Islamic teachings and religious values. Therefore, the meanings implied in these poems need to be studied, revealed, and used as the guidelines for living in the society (Syatayawi, 2013:18)

Imam Ali ibn Abi Talib was born in 600AD. His full name is Ali ibn Abi Talib ibn Abdul Muttalib ibn Hashim ibn Abdi Manaf. He is the cousin of the Prophet Muhammad and the husband of the Prophet's favorite daughter, Fatima (Syatayawi, 2013:20; Hitti, 2013:223). He was the fourth caliph during the reign of Khulafa' ar-Rashidin who was appointed in 656-661 AD to replace Caliph Uthman ibn Affan. In 661 AD. He was killed by one of Khawarij's followers, Abdurrahman ibn Muljam when he was about to leave for prayer to the Kufa mosque (Syatayawi, 2013:20; Hitti, 2013:227).

In the literatures of the Arabic literature history, Imam Ali was not included in the ranks of Arabic poets in the early Islamic era, although his works are a masterpiece known by entire intellectuals around the worlds. This is probably because he did not make any specific literary work, but only limited to expressing his heart and mind (to his friends and followers) for the phenomena and events occurred around him at that time.

Although the Arab society at the early history of Islam had begun to recognize the education and teaching of Islam directly from the Prophet Muhammad and recognize the Quran as a guide to their lives, there were still some Arab communities who had not fully obeyed those teachings and commands from the Prophet.

For this reason, probably, as the successor of the preaching of the Prophet Muhammad, Imam Ali frequently delivered the Islamic teachings to his family, friends, and even to those who 


\section{Arabi : Journal of Arabic Studies}

hated him through the poems which he absorbed and learned from the teachings of the holy Quran and the Sunnah from the Prophet. This way was adopted by Imam Ali due to the poetry, as conveyed in the initial paragraph, is the great cultural identity of the Arab society. He hoped that this delivery and persuasion (da'wah) would be more effective and could touch their hearts and minds.

Language as a medium of literary work (poetry) is a semiotic system (signification) which meaning is based on community or society conventions (Mahliatussikah, 2015:103). The meaning of language contained in the literary works is the first level of sign system, while the literary meaning, which is higher than the language one, is the second level of sign system (meaning of meaning) (Pradopo, 2010:122; Mahliatussikah, 2015:103). The language of poetry, then, can be elevated up to so high levels of performance in poetry as to turn into a verbal substitute for the reality it chooses to convey (al-Zubaidy, 2014:11).

The poems attributed to Imam Ali contain many moral messages in signs in the form of words or expressions at the verses of his poems. Therefore, it is necessary to do an analysis to uncover the meanings of these poems so that they can be read clearly and understood by the public and used as guidelines for daily life. In order to uncover and interpret the hidden signs in these poems, the semiotic analysis formulated by Michael Riffaterre in his book "Semiotics of Poetry" (1978) is used. Semiotics is a suitable analysis to be used as a tool to uncover hidden meanings in signs, which in this case could be hidden in each linguistic unit of the poems. As mentioned before, the poetry has a set of sign system that needs to be analyzed to reveal its implied meaning, because it is slightly difficult to grasp it immediately without using appropriate analysis.

Some previous research works related to the moral messages in Arabic poems including Imam Ali's masterpiece have been done. One of them is a paper entitled "Nilai-Nilai Moralitas dalam Syair Jahiliyah Karya Zuhain Ibnu Abi Sulma" (Moral Values in the Pre-Islamic Poems by Zuhair ibn Abi Sulma) written by Buana (2017). This paper discusses the moral values implied by Zuhair ibn Abi Sulma, one of the famous poets in pre-Islamic (Jahiliyyah) era.

Another research related to one of Imam Ali's masterpiece known as Nahjul Balaghah (Sermons, Letters, Sayings, of Imam Ali ibn Abi Thalib) has been done by Qutbuddin (2012) in his paper entitled "The Sermons of Ali ibn Abi Thalib: At the Confluence of the Core Islamic Teachings of the Quran and the Oral Nature-Based Cultural Ethos of Seventh Century Arabia". This paper discussed and explored the core Islamic teachings and their religious and cultural underpinnings through a close reading of his most celebrated discourse.

The other paper specifically related to Imam Ali's poems is written by Hanif (2004) entitled "Relevansi Sya'ir Ali bin Abi Thalib terhadap Prinsip-Prinsip Pendidikan Modern" (The Relevance of Imam Ali bin Abi Thalib's Poems to the Principles of Modern Education). This paper discussed the contents of Imam Ali bin Abi Talib's poems, but the discussion here is limited to the relevance of the content or message conveyed in these poems with the principles of modern education and does not discuss the moral messages contained in the poems in its entirety.

As stated in the preceding paragraphs, it is known that the previous studies about the values and moral messages contained in Arabic poetry have been widely carried out (Buana, 2017; Nurain, 2014). In fact, the research on the works of Imam Ali ibn Abi Talib has also been done, both in his poetry (Hanif, 2004), as well as in his other masterpiece called Nahjul Balãghah (Quthbuddin, 2012). However, based on the results of those studies, the research of moral values contained in the poems attributed to Imam Ali has not been deeply studied; as a result, -in the opinion of researchers- it seems necessary to explore deeper and broader to reveal the valuable moral messages in Imam Ali's poems using the right analysis, namely semiotics. By relying on this analysis, the implied meanings in words or sentences at the verses of this poem can be revealed, learned, and understood by the public as a guide for their daily life. 


\section{Method}

There are three stages of research conducted in this paper, namely collection of data, analysis of data, and presentation of the results (Sudaryanto, 2015:6). The data collected and analyzed in this study were taken from a collection of poetry books entitled "Diwan al-Imam Ali" (The Anthology of Imam Ali). This book is a collection of Imam Ali's poem compiled from various sources by Ahmad Ahmad Syatayawi (2013). The poems in this anthology are arranged according to the rhymes (qafiyah) and grouped according to their metrics (bahr).

To analyze the signs or meanings in a poem, it is necessary to do a semiotic analysis in descriptive-analytic framework that emphasizes systematic interpretation from of the individual point of view or population being studied to generate new concepts (Mohajan, 2018:2). There are four steps need to be taken to reveal the meaning of the signs contained in the poem. These steps are (1) determining the continuity of expression, (2) reading heuristics and hermeneutics, (3) scanning of matrixes, models, and variants, and (4) determining the hypograms (Riffaterre, 1978:4-6 \& 19-22; Mahliatussikah, 2015:104-106).

However, the focus of the analysis in this study is only on the most important steps of analysis, heuristic and hermeneutic reading (Riffaterre, 1978:5-6). The heuristic reading is the naturalization of the language of poetry into ordinary language in accordance with normative grammar or interpretation referentially through the linguistic signs, while the hermeneutic one is a retroactive reading after heuristic reading by giving the literary convention, namely the second order of semiotic system (second order of semiotics) including the indirection of poetic language expression (Riffaterre 1978:5-6; Mahliatussikah, 2015:105). Thus, the heuristic reading needs to be done to find out the language convention, then it should be continued to the hermeneutic (retroactive) reading to find out their literary convention.

The result is presented in several steps:

1. Transliterating the poems from Arabic into Latin letters according to the applicable guidelines with some changes for the sake of readability and mastery. The transliteration used in this paper refers to the Arabic-Latin Transliteration Guidelines based on the Joint Decree of the Minister of Religion and the Minister of Education and Culture of the Republic of Indonesia No. 158 of 1987 and No. 0534 /b/U/1978 on September $10^{\text {th }}, 1987$, with some minor changes. The change lies in the writing of several consonants, referring to the changes formulated by Hadi (2003: xxxiii-xxxv)

2. Translating and describing the poem into English in accordance with the rules or grammars of the language to make it easier for the researcher to interpret the content of the poems

3. Giving the meanings and explanations towards the signs found in each stanza in the poems based on the language and literary conventions.

\section{Result and Discussion}

Based on the analysis, it is found that the poems of Imam Ali contained and implied many valuable moral messages and wisdoms which are very important to be studied, revealed, explained, and known by the public. The valuable moral messages conveyed by Imam Ali in the verses of his poems are mainly originated from the values of Islamic teachings contained in the Quran and the Hadith of the Prophet Muhammad PBUH.

\section{The Primacy of Seeking Knowledge and Science}

$$
\text { (1) العلم زين فكن للعلم مكتسبا - وكن له طالبا ما عشت مقتبسا }
$$

Al-'ilmu zainun fa kun li al-'ilmu muktasiban, wa kun lahu thā liban mā 'isyta muqtabasan

"Science is a beauty, so be a smart person and be a seeker of science (knowledge) for your life so that you will be useful" 


\author{
(r) أركن إليه وثق بـالله واغن بـه - وكن حليمـا رزين العقل محترسا \\ Urkun ilaihi wa tsiq billahi waghni bihi, wa kun chatiman \\ raz̄nu al-'aqli muchtarisan \\ "Rely on it (the science), believe in God, trust yourself with it \\ (the science), be wise, always take care of yourself"
}

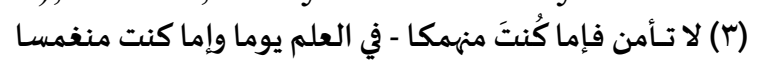

La tuammina fa imma kunta munhakiman, fi al-'ilmi yauman wa imma kunta munghamisan

"Do not be weak when you are serious about (seeking) science one day, even when you are engrossed in it (science)"

$$
\text { وكن فتى ماسكا محض التقى ورعا - للدين مغتنما للعلم مفترسـ (ع) }
$$

Wa kun fatā māsikan machdha at-taqā wa ra'ā, li ad-dinni mughtaniman li al-'ilmi muftarasan

"Be a young man who holds firmly to pure devotion, who always preserves religion and (preserves) science"

$$
\text { (0) فمنْ تخلق بـالاداب ظل بها - رئيس قوم إذا ما فـارق الرؤساء }
$$

Fa man takhluqu bi al-ā dābi zhalla bihā, raìsu qaumin idzā māa fâraqa ar-ruasāa

"Whoever behaves with manners then he always becomes a leader even though he has separated from his head (died)"

$$
\text { (7) واعلم هديت بأن العلم خير صفا - أضحى لطالبه من فضله سلسا }
$$

Wa'lam hadaita bi anna al-'ilma khairu shaffa, adhchā li thālibihi min fadhlihi salsa

"Know that that science will give clues to the best of holiness, which with its virtue (science) makes its seekers the good person"

In general, the fragment of the poems above contains an important moral message about the primacy of science or knowledge and the virtues of smart people. In verse (1) Imam Ali compared the science/knowledge with a beautiful jewelry (zainun). Jewelry is an object to decorate or beautify ourselves. The message delivered to the audience in this fragment of the poem is to always adorn themselves with knowledge or science so it would benefit the community.

Learning is very important to realize the happiness of living in this world and the hereafter. Without a proper of knowledge, humans cannot do anything. To make a living, for an example, needs a proper knowledge, to do good worships needs a proper knowledge, even to eat and drink needs a proper knowledge as well. Thus, learning is undeniable, because it is related to one's obligations as a servant of Allah SWT. If a person does not know his obligation as a servant, he couldn't get any salvation in this world and the hereafter (Lubis, 2016:229).

Imam Ali's message about the primacy of seeking knowledge is in line with the teachings of Islam (the teachings that originate from al-Quran and Hadith of the Prophet Muhammad). There are so many verses in the Quran and Hadith of the Prophet Muhammad that discusses about the primacy of knowledge. Here is one of them:

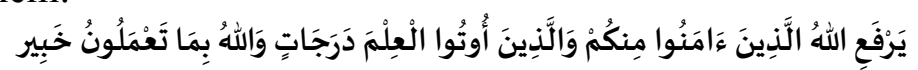

" Allah will raise those who have believed among you and those who were given knowledge, by degrees. And Allah is Acquainted with what you do" (58:11)

The verse implies that the position of people who believe and have knowledge have a higher position before God Almighty. This shows that the role of knowledge in some one's life is very large and important, because the degrees of one human being could be distinguished by their knowledge and faith (Ulum, 2019:58). Furthermore, in verse (2-4) Imam Ali advised the young people to really hold fast to knowledge and always enrich themselves with knowledge because 
knowledge will bring wisdom to their owners. In addition, he also advised that to always maintain and integrate science (al-ilm) and religion (ad-din) as a form of pure devotion to Allah SWT.

In the last two verses (5-6), Imam Ali said that knowledge would give instructions to the owner and could also cause the owner to become a better person. Because with knowledge, a person can recognize and consider everything related to himself and to the surrounding environment as well.

From the explanation above, it is not surprising that the Prophet Muhammad also obliged everyone to study. He (Prophet Muhammad SAW) said:

$$
\text { طلب العلم فريضة على كل مسلم }
$$

"Seeking knowledge is obligatory for every Muslim" (al-Albani, 1988: 727)

Thus, there is no reason for anyone not to seek of science or knowledge. All men and women, young and old, rich and poor, etc., have the same obligation to seek knowledge, without exception.

2. The Primacy of Intellect and Reason

$$
\text { فلوكانت الدنيا تنال بفطنة - وفضلٍ وعَقُلٍٍ نلتُ أعلى المراتب }
$$

Fa lau kānat ad-dunyā tanāla bi fathanatin, wa fadhlin wa 'uqulin niltu a'la al-marātibi

"If this world were obtained with ingenuity, excellence, and rationality, then I would have obtained the highest rank"

$$
\text { ولكنّمـا الأرزاقُ حظُّوقِسمة - بفضِلِ مليكِ لا بحيلة طـالب }
$$

Wa lakinnamā al-arzāqu wa qismatun, bi fadhli mă̌ kin lā bi chīlati thālibin

"But wealth is a fortune and its distribution solely with the virtue of Allah, not with one's ingenuity"

$$
\text { (9) وأفضل قسم الله للمرء عقلـه - فليس من الخيرات شيء يقاربه }
$$

Wa afdhalu qassamallahu li al-mari 'aqlahu, fa laisa min al-khairāti syaiun yuqā ribuhu

"And the best part of giving from Allah to a human being is his mind (brain), not all other good things that are close to him"

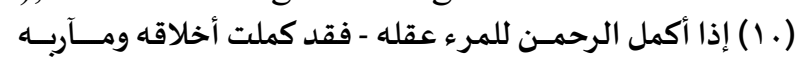

Idzā akmala ar-rachmānu li al-mari 'aqlahu, fa laqad kamilat akhlā quhu wa māā ribuhu

"When the Most Merciful has perfected one's intellect (brain), then it has been perfected character and purpose as well"

$$
\text { ، يعيش الفتى في الناس بالعقل إنه - على العقل يجري علمه وتجاربه }
$$

Yàisyu al-fatā fi an-nāsi bi al- 'aqli innahu, 'alā al- 'aqli yajn̄ 'ilmuhu wa tajāribuhu

"A young man lives in (the middle of) society with his mind, because with his mind, the knowledge (science) and his behavior goes"

$$
\text { (r ( ) يزين الفتى في الناس صحة عقله - وإن كان محظورا عليه مكاسبه }
$$

Yaz̄nu al-fatā fi an-nāsi shichchata 'aqlihi, wa in kāna machzhūran 'alaihi mukā sibuhu

"A young man becomes noble in (the middle of) society with his reasoning sanity, because if it is blocked (his mind is closed) then the loss will befall to him"

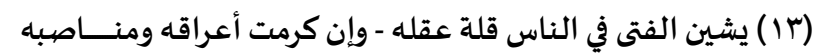

Yasȳinu al-fatā fi an-nasi qillata 'aqlihi, wa in karumat a'rāquhu wa manā shibuhu 
"A young man becomes a disgrace in (the middle of) society because of his lack of reason/mind, even though his ancestry and position are respected"

$$
\text { (ع ( ) ومن كسان غلابا بعقل ونجدة - فذو الجدِّ في أمر المعيشة غالبُه }
$$

Wa man kāna ghalāban bi 'aqlin wa najdatin, fa dzū al-jaddi fi amri al-ma`isyati ghālibuhu

"And whoever (succeeds) reaches with reason and courage, then he will earnestly in the affairs of life (also)"

The fragment of the poem above contains a moral message about the primacy of intellect or reason as the gift from Allah. According to Garrath (2016), reason is an important source of the unifying structure of experience. It proves essential as an arbiter of empirical truth. He added that the reason can also be the source of unconditional demands, demands that do not presuppose any particular ends or inclinations.

In the verses (8) and (9) Imam Ali indicated that the reason (al-'aqlu) is the most important gift from Allah for humans, not the wealth (al-arzaq). These verses also emphasized that there wasn't even anything that could equal it or even approach it. This shows that the reason does have extraordinary feat ures compared to other creations of Allah.

Based on the observation of M. Quraish Shihab (2018), the word aqala (thinking/reasoning) found in the majority of the Quran is in the form of the verb, namely ya'qilün (they are intelligent/ thinking) and ta'qilūn (you are intelligent / thinking). Each appears in the Koran 22 and 24 times. In addition, there are also the words na'qilu (we are intelligent/ thinking) and 'aqluha (their minds) and aqaluhu (their minds), each of which is mentioned once in the Quran. The repetition of the word "al- 'aql" and its various forms in such a large number implies the importance of the role of reason. ${ }^{1}$

Verses (11) to (13) in the fragment describe the correlation between a person's intellectual capacity and function in daily life. If someone has a healthy mind (has a good logical ability), he will be useful for community life. On the contrary, if the person has a defective mind (lack of reason), then of course he could not live well in society, even if he is a descendant of someone having an honored position. It is not impossible that a person's disability would be a disgrace to himself and to those around him.

\section{The Primacy of Silence}

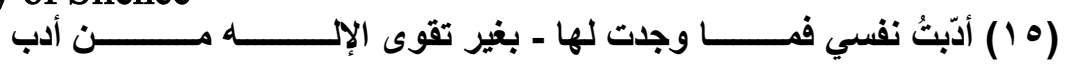

Addabtu nafsī fa mā wajadtu lahā, bighairi taqwā al- 'ilāha min adabin

"I corrected my own morals when I found in them without any devotion to God at all"

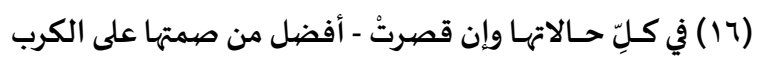

Fì kulli chā lā tihā wa in qashurat, afdhalu min shamtihā 'alā al-karbi "Although limited (not capable) in all conditions, it is better than silencing it above the distress"

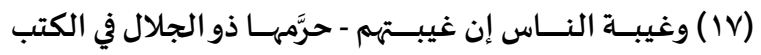

Wa ghībatu an-nāsi inna ghībatahum, charramaā dzū al-jalāli fi alkutubi

"And (about) human gossip, that in fact their gossip has been forbidden by the Owner of the Greatness (Allah) in the books"

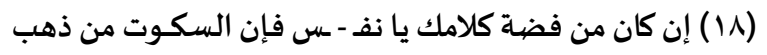

In kāna min fidhdhatin kalāmuka ya nafs, fa inna as-sukūta min dzahabin

\footnotetext{
${ }^{1}$ Read more in "Arti Penting Menggunakan Akal Menurut Alquran ", https://tirto.id/cpUn 
"If your words (words) are made of silver, O soul, then your silence is made of gold"

This fragment of the poems generally contains a moral message about the importance of silence. In verse (18), Imam Ali compared the speech (al-kalam) as silver (al-fidldlah) while the silence (as-sukut) as gold. Such a parable suggests that silence is better than speech. Of course, what is meant by speech in this case is the disgraceful speech.

This fragment of the poems also has an equivalent meaning and moral message with the following Hadith of the Prophet Muhammad (al-Bukhari, 2002:1509):

من كان يؤمن بالله واليوم الآخر، فليقل خيرا أو ليصمت، ومن كان يؤمن بالله واليوم الآخر، فليكرم جاره، ومن كان يؤمن بالله واليوم

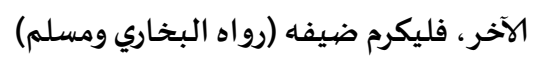

" Whoever believes (have faith) in Allah and the Judgement Day then say well or be silent, and whoever believes in Allah and the Judgement Day then glorify his neighbors, and whoever believes in Allah and the Judgement Day then glorifies his guests (Narrated by Bukhari and Muslim)"

This hadith explains that there are three preconditions for a person to be recognized as a person who believes in Allah and the Judgment Day. First, someone should speak with good ethics or if not, then it is better for him to be quiet. Second, he respects his neighbors around his residence. Third, he respects guests who visit his home.

The silence of a person is considered better if the preconditions contained in the imperative sentence "falyaqul (qaulan) khairan" or "speaking with good words" are not fulfilled. Furthermore, the context related to what kind of words are categorized worse than silence needs to be seen clearly. If the content of verse (18) is being connected to the content of previous verse (17), it can be seen that bad words are words that contain a backbiting or gossip (ghibatu an-nās).

The backbiting or gossip or talking about bad/disgrace someone is an act that is forbidden by Allah, as conveyed in the Quran Surah al-Hujurat verse 12 below:

ميتا فكرهتموه واتهوا الذين آمنوا اجتنبوا كثيرا من الظن إن بعض الظن الظواب إثم وحلا تجسسوا ولا يغتب بعضكم بعضا أيحب أحدكم أن ياكل لحم أخيه

"O you who have believed, avoid much [negative] assumption. Indeed, some assumption is sin. And do not spy or backbite each other. Would one of you like to eat the flesh of his brother when dead? You would detest it. And fear Allah; indeed, Allah is Accepting of repentance and Merciful." (49:12)

In this verse, Allah likens those who like to gossip or talk about someone's disgrace like a person who eats the flesh of his own brother. The remodelling shows that backbiting or gossip is something very disgusting and hated by Allah. Consequently, if this action did by someone, then he will get a big sin. In this case, no wonder that Imam Ali likens the silence as gold, while the (bad) speech as silver.

\section{Keeping Away from Greedy}

$$
\text { (19) دع الحرص على الدنيا - وفي العيش فلا تطمغ }
$$

Da' al-chirsha 'alā ad-dunyā, wa fi al-'aisyi falā tathma'

"Keep away from greedy of the world and do not be greedy in life"

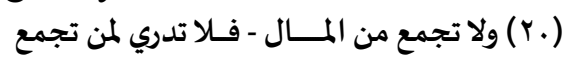

Wa là tajma' min al-māli, fa lā tadī li man tajma'

"And do not you (love) to collect property, if you do not know whose property you collect it"

$$
\text { ولا تدري أفي أرضـك - أم في غيرهـا تصرع (Y) }
$$

Wa là tadrī afi ardhika, am fi ghairihā tashra'

"And you do not know whether in your territory or in the territory of others you stand for" 


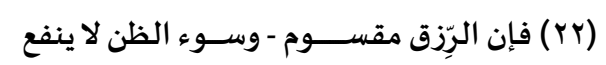

Fa inna ar-rizqa maqsūmun, wa sūa azh-zhanni la yanfa'

"Because actually the fortune has been divided, so that prejudice is not useful at all"

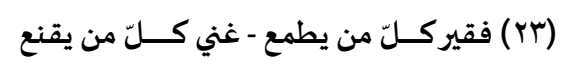

Faqi run kullu man yathma', ghaniyyun kullu man yaqna'

"A poor person is everyone who is greedy, (whereas) a rich person is anyone who feels enough"

This fragment of the poems contains a moral message to move away from the greediness towards the worldly affairs. This can be directly seen in verse (19), which Imam Ali explicitly appealed to avoid (al-hirshu) the greedy and rapacious (ath-tham'u) towards worldly affairs. Greedy is having or showing a selfish desire for wealth and possessions (Merriam-Webster, 2019). Thus, the greedy towards the worldly affairs indicates the feeling of someone who always feels his life needs are never fulfilled, so that in his heart always wants more than what he has got.

Greed is often seen as immoral. The assumption that greed elicits unethical behavior is widespread. Greedy people were more likely to take a bribe and also preferred higher bribes. Greedy people were more likely to transgress because they found the positive outcomes associated with the transgression which is more desirable for them, and therefore displayed lower self-control (Seuntjens, et.al, 2019:147).

The greedy often necessitates the process of fulfilling desires/ needs in ways that are not good or justified. This is in line with what was said by Imam Ali in verse (21) in the fragment above. The limits in fulfilling the desires, which is likened to the term ardhun or region (earth), became the vague (unclear) because basically the greedy knew no boundaries.

The moral message about excessive to the world (al-chirshu ala ad-dunya) contained in the verses (19) above has the following correlation with the words of the Prophet Muhammad (alAlbani, 2007: 15):

$$
\text { اقتربت الساعة ولا يزداد على الناس إلآ حرصًا، ولا يزدادون من الله إلّا بعدًا }
$$

"The Day of Judgment is getting closer, and it is not increasing (willingness) of people but rather getting greedy, and not increasing (their closeness) to Allah, but the further"

This quote from the Prophet Muhammad indicates that the greedy towards the worldly affairs are signs of the Judgement Day. Thus, as stated by Imam Ali in his poem, it needs to be emphasized that the moral message from this poems is to stay away from the greedy and prioritize the conviction or willing to accept and always feel enough with the gift of Allah through the results of the business that has been done to the maximum effort.

\section{Patient Against Insults and Reproaches}

$$
\text { (Y) وذي سفه يواجني بجهل - وأكره أن أكون له مجيبـ }
$$

Wa dz̄ safahin yuwājihuni bi jahlin, wa akrahu an akūna lahu muji ba

"The fool (who likes to insult me) is facing me with ignorance, and I hate to serve him"

$$
\text { (ro) }
$$

Yaz̄idu safāhatan wa az̄ du chilman, ka 'ū din zā da bi al-ichrāqi thìban

"His folly grows, while I am wiser, like agarwood that becomes more fragrant when burned"

The fragment of the poems above contains a moral message about the patient with all kinds of insult from the fool (as-safih). In verse (24), Imam Ali is clearly stated about his ignorance or hatred towards the fool who often denounced or insulted him. Ibn Mandzur (1994:497) defines asSafih (the fool) or as-Safahah (foolishness) as al-jahlu (ignorance), khiffatu al-hilmi (weakness of 
insight, wisdom, reason or patience), or naqishu al-chilmi (lack of insight, wisdom, reason or patience). These three terms have interrelated meaning, namely no enough sense or adequate knowledge as a provision in society.

Further information about the phenomenon of as-safih (the fool) can be seen in the Hadith of the Prophet Muhammad (Hanbal, 1997: 291) below:

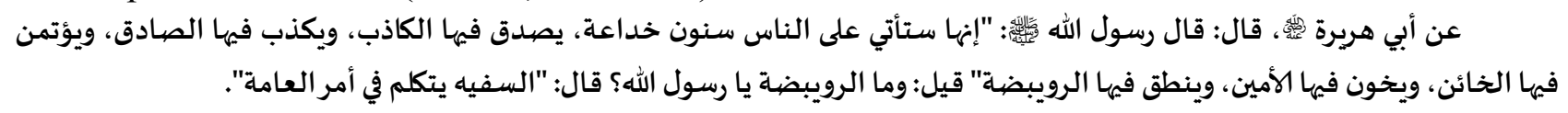

"From Abu Hurairah RA said: Rasulullah SAW said: Indeed, people will come to the years of deception, in which people who lie are trusted while honest people are denied, people who betray are given a mandate while people who are trustworthy are betrayed, and in it there are also arRuwaibidhah. Rasulullah was asked: What is ar-Ruwaibidhah O Messenger of Allah? He replied: The fools who speak (give fatwas) in public affairs (humans)."

The hadith above implies that the words or speech of the fools are completely useless, even inclined to be a dangerous. Therefore, we should not need to pay attention to everything he says. However, perhaps if possible, it is necessary to carry out the "ar-raddu ala as-safih" (fight against such fools) movement through various efforts, such are the good distribution of education and counter-narrative statements of the fools who could be harming the religion, the nation, and the state.

In the verse (25) Imam Ali compared those who are patient to the reproach or insult of the fools as the agarwood ( ' $u d$ ). When this wood is burned, it will produce a sweet fragrance. Quoting from Wikipedia (2019), agarwood is blackish-colored wood and contains typical resins produced by tree species of the genus/genus Aquilari. The resin is used in the perfume industry because it smells good. This comparison shows that the more patient a person with all kinds of insults, the wiser he will be.

Insulting is one of rude and impolite actions. One form of one's impolite actions towards others occurred massively nowadays is in terms on language impoliteness. Language impoliteness is defined as a language activity which is aimed to damage interpersonal relationships or deliberately attack the face of the speech partner (Yuanita, 2019:283). Furthermore, Culpeper (1996) said that impoliteness is the opposite of politeness that is "the use of strategies that are designed to have the opposite effect - that of social disruption" or strategies used to damage social relations between speakers. Therefore, we need to be careful, especially in safeguarding our language, so that we are not classified as as-Safih who like to carry out such dishonorable actions.

\section{Conclusion}

Based on the result and discussion, it can be concluded that the classical Arabic poetry, especially in the beginning of Islamic era, contains many lessons and valuable moral messages that we can learned from. One of them is the poems attributed to of Imam Ali which contain and imply some moral messages such as (1) the primacy of seeking knowledge and science, (2) the primacy of intellect and reasoning, (3) the primacy of silence, (4) keeping away from greedy, and (5) patient with all kinds of insult. These messages certainly can be used as the guidelines for the daily life in society, because they are in line with the Islamic teachings. This research is a preliminary study, and needs to be followed by similar studies with a wider range of data and a more diverse analysis. Hopefully, the research on Arabic literature at the classic period or at the beginning of Islamic era can enrich the treasury of Islam and ground it as a part of rahmatan li al- 'alamin (a blessing for all nature).[] 
Arabi : Journal of Arabic Studies

\section{References}

al-Albani, M.N. 1988. Shahih al-Jami ash-Shaghir wa Ziyadatuhu (al-Fath al-Kabir). Beirut: alMaktab al-Islami

al-Albani, M.N. 2007. Silsilatu al-Ahadits ash-Shahihah; Jilid ke-3. Riyadh: Maktabah al-Maarif

Asriyah. 2016. "Perkembangan Sejarah Sastra Arab”, Rihlah: Jurnal Sejarah dan Kebudayaan, Vol. 5, No. 2.

Badawi, M.M. 1975. A Critical Introduction to Modern Arabic Poetry. London: Cambridge University Press.

Bakalla, M.H. 1984. Arabic Culture Through Its Language and Literature. London: Kegan Paul Internasional.

Buana, Cahya. 2017. "Nilai-Nilai Moralitas dalam Syair Jahiliyah Karya Zuhain Ibnu Abi Sulma", Buletin Al-Turas: Mimbar Sejarah, Sastra, Budaya, dan Agama, Vol. 23, No. 1.

al-Bukhari, Abi Abdullah Muhammad bin Ismail. 2002. Shahih al-Bukhari. Beirut: Dar Ibnu Katsir.

Culler, Jonathan. 2001. The Pursuit of Signs: Semiotics, Literature, Deconstruction. London: Routledge Classics

Culpeper, Jonathan. 1996. “Towards an Anatomy of Impoliteness”, Journal of Pragmatics, Vol. 25, No. 3.

Garrath, W. 2016. "Kant's Account of Reason: The Stanford Encyclopedia of Philosophy", retrieved from: https://plato.stanford.edu/entries/kant-reason

Hadi, Syamsul. 2003. "Kata-Kata Serapan dari Bahasa Arab yang Terdapat dalam Kamus Besar Bahasa Indonesia", Disertasi, Universitas Gadjah Mada.

Hanbal, Ahmad bin. 1997. Musnad al-Imam Achmad bin Hanbal. Beirut: Muassasah ar-Risalah.

Hanif, Moh. 2004. "Relevansi Syair Ali bin Abi Thalib terhadap Prinsip-Prinsip Pendidikan Modern", Tesis, UIN Walisongo Semarang.

Hitti, Philip K. 2013. History of The Arabs. Diterjemahkan dari History of The Arabs; From the Earliest Times to the Present oleh Cecep Lukman Yasin dan Dedi Slamet Riyadi. Jakarta: PT Serambi Ilmu Semesta.

Lubis, Zulfahmi. 2016. "Kewajiban Belajar", Ihya al-Arabiyah: Jurnal Pendidikan Bahasa dan Sastra Arab, Vol. 2,No. 2.

Mahliatussikah, H. 2015. Pembelajaran puisi: teori dan penerapannya dalam kajian puisi Arab. Malang: Universitas Negeri Malang.

Mandzur, Ibnu. 1994. Lisan al-Arab: Jilid ke-13. Cetakan ke-3. Beirut: Dar Shadir.

Manshur, Fadlil M. 2007. "Sejarah Perkembangan Kesusastraan Arab Klasik dan Modern", paper presented in Seminar Internasional Bahasa Arab dan Sastra Islam: Persoalan Metode dan Perkembangannya on 23-25 Agustus 2007.

Merriam-Webster. 2019. Greedy. https://Www.merriam-webster.com/dictionary/greedy accessed on July 30, 2019.

Mohajan, H. 2018. "Qualitative Research Methodology in Social Sciences and Related Subjects”, Journal of Economic Development, Environment and People, Vol. 7, No. 1. 
Nurain. 2014. "Nilai-Nilai Kehidupan dalam Puisi Al-Mutanabbi", Adabiyyat: Jurnal Bahasa dan Sastra, Vol. 13, No. 2.

Quthbuddin, Tahera. 2012. "The Sermons of Ali ibn Abi Thalib: At the Confluence of the Core Islamic Teachings of the Quran and the Oral Nature-Based Cultural Ethos of Seventh Century Arabia", Anuario de Estudios Medievales, Vol. 42, No. 1.

Riffaterre, M. 1978. Semiotics of Poetry. London: Indiana University Press.

Seuntjens, T. G., Zeelenberg, M., van de Ven, N., \& Breugelmans, S. M. 2019. "Greedy Bastards: Testing the Relationship between Wanting More and Unethical Behavior”, Personality and Individual Differences, Vol. 138.

Shihab, M. Quraish. 2018. “Arti Penting Menggunakan Akal Menurut Alquran”, Retrieved from: https://tirto.id/arti-penting-menggunakan-akal-menurut-alquran-cpUn accessed on July 25, 2019.

Sudaryanto. 2015. Metode dan Aneka Teknik Analisi Bahasa. Yogyakarta: Sanata Dharma University Press.

Syatayawi, A.A. 2013. Diwanu al-Imam Aliyyi. Kairo: Dar al-Ghad al-Jadid.

Pradopo, R.J. 2010. Pengkajian Puisi. Yogyakarta: Gadjah Mada University Press.

Ulum, M. Miptakhul. 2019. “Ilmu Pengetahuan dan Al-Qur'an (Diskursus Realitas Fenomena Alam)”, La-Tahzan: Jurnal Pendidikan Islam, Vol. 11, No. 1.

Yuanita, Arie. 2019. "Language Impoliteness in Stand-up Comedy Academy (SUCA) II on Indosiar", paper presented at3rd Social Sciences, Humanities, and Education Conference (SoSHEC).

Zaidan, Jurji. 2013. Târikh Ādābi al-Lughah al-'Arabiyyah. Kairo: Hindawi

al-Zubaidy, Adil Saleh. 2014. "The Language of Poetry: Tool or Performance? A Stylistic Analysis of a Classical Arabic Line of Verse", Procedia - Social and Behavioral Sciences, Vol. 158. 